Article

\title{
Why Developing Countries Go through an Unsustainable Energy Transition Pathway? The Case of the Philippines from a Political Economic Perspective
}

\author{
Phoebe Grace Saculsan *, Akihisa Mori \\ Graduate School of Global Environmental Studies (GSGES), Kyoto University, \\ Kyoto, 606-8501, Japan \\ * Correspondence: Phoebe Grace Saculsan, Email: pjsaculsan@gmail.com; \\ Tel.: +81-8095450407.
}

\begin{abstract}
A shift toward a sustainable energy system takes place when renewable energy technologies become much more appealing energy options. However, political factors deter many developing countries from deploying renewable energy. This paper aimed to elucidate how exogenous actors and regime incumbents exercise power to block renewable energy technologies from emerging in developing countries, using the Philippines as a case study. This work uses a combination of a multi-level perspective in socio-technical transitions with power exercises as the analytical framework. The results show that in the Philippines three types of power exercises have moved the country toward a coal-based energy system. First, multilateral banks and foreign investors exercised a transformative power to pressure the government to liberalize the energy system, and currently exercise this power to support the development of both coal and renewable energy, albeit more indirectly. Second, "energy oligarchs" exercise reinforcive power to create and reproduce a new private oligopolistic energy structure by acquiring energy assets, building coal power plants, and dominating the energy supply chains. Lastly, the government exercises the constitutive and transformative power to induce these foreign investors and energy oligarchs to continue investing in coal power unless renewables can sufficiently contribute to energy security and affordability of electricity prices. These findings imply that in developing countries the liberalization of the electricity market can result in a change to the dominant power structure from a government monopoly to a private oligopoly and accelerate the transition to a coalbased energy system.
\end{abstract}

\section{G Open Access}

Received: 03 October 2019 Accepted: 05 February 2020

Published: 11 February 2020

Copyright (C 2020 by the author(s). Licensee Hapres, London, United Kingdom. This is an open access article distributed under the terms and conditions of Creative Commons Attribution $\underline{4.0 \text { International License. }}$

KEYWORDS: energy transitions; political economic perspective; multilevel perspective; energy oligarchs; the Philippines 


\section{ABBREVIATIONS}

MLP, multi-level perspective on socio-technical transition; EPIRA, Electric Power Industry Reform Act; FIT, feed-in tariff; clean coal technology (CCT)

\section{INTRODUCTION}

Growing concern about climate change and volatility in the price and supply of fossil fuels is leading many countries to allow more renewable energy in their current energy system [1]. Renewables are seen to have the potential to address the environmental and climatic challenges that are associated with the use of fossil fuels, and to bring about co-benefits such as employment generation [2]. These potentials have propelled the continued growth of renewables in recent years. Wind, solar, bioenergy and waste, geothermal, small hydro, and tidal account for nearly $62 \%$ of net additions to the global power generating capacity, increasing from 161 GW in 2016 to $181 \mathrm{GW}$ in 2018 [1]. Most of this increase occurred in wealthy nations such as the United States, China, and the UK, whereas relatively small contributions were seen from developing countries (except China and India). In fact, in any given year since 2010, no more than 27 developing countries have attracted over 100 million USD for the construction of a single utility-scale wind or solar project [3].

Developing countries have suffered from a number of barriers to renewable energy deployment, ranging from difficulty accessing finance, bureaucratic and administrative red tape, and social acceptance ("NIMBY"), to concerns regarding energy security. All of these barriers are related to weak institutions and governance, and the dynamic socialpolitical conditions that exist in developing countries [2,3]. Additionally, the transition from a fossil fuel-based energy system toward a renewables based system requires higher reconfiguration capacity and the process of experimentation, configuration, and selection [4]. It also encompasses high sunk costs associated with large-scale generation, social embedding, and complementarities around the renewables-based system that lead to transaction costs in the transition from a fossil fuel-based energy system to a renewables-based one. These transaction costs can be especially high for regime incumbents, who may lose their vested interests and coalitions by promoting such a transition [5] and may therefore resist spreading renewable energy to protect their interests [6]. These regime incumbents exercise constitutive power over a long time period, and therefore conventional energies such as coal and nuclear energy are becoming more institutionally and technologically "locked-in", making it ever more difficult to transition to renewable energy [7].

Political factors potentially affect energy transitions [8], but the effects remain unclear in the literature [5]. Understanding this influence is crucial to facilitating energy transitions. Instead of merely investigating how to facilitate the adoption of renewables, this paper considers how regime actors obtain and maintain power that inhibits the adoption of 
renewables [9]. Understanding these factors could help clarify the complexities of power dynamics at the regime level and could perhaps be utilized to weaken and topple the regime actors.

This paper aimed to elucidate how exogenous actors and regime incumbents in developing countries exercise power to block the adoption of renewables, using the Philippines as a case study. The rest of the paper is organized as follows: First, we provide an analytical framework to justify why the concept of power should be incorporated into a multi-level perspective (MLP) of socio-technical transitions. Second, we describe the historical energy transition pathway in the Philippines. Third, we analyze how the power exercise between exogenous actors and endogenous regime incumbents blocks the emergence of renewables. Fourth, we provide an in-depth exploration of the implications of power relations on energy transitions, and finally, we present the conclusions.

\section{ANALYTICAL FRAMEWORK}

Central to the discussion of sustainable energy transitions is the mechanism by which clean energy alternatives could overthrow the prevailing fossil energy regime, which is locked-in and path-dependent in relation to fossil energy sources. Unruh [10] describes these two mutually related concepts as being driven by the interlocking and co-evolution of a technological system, institution, and social forces, which create a development pathway that makes replacement of fossil energy with sustainable energy sources difficult. Economy of scale of a carbon-based energy infrastructure and the strengthening of the technological institutions that support this infrastructure further entrenches the traditional energy system.

The MLP allows deeper understanding of the process of knowledge politics, political conflict and accommodation, and bargaining and disciplining in energy transitions [11]. It has been used to analyze the developments and interactions between three levels: landscape, regime, and niche innovations [12]. The top-tier landscape level is the exogenous macro-level environment that can induce pressure on or affect the incumbent socio-technical regime and technological niches. It can put pressure on the regime or provide opportunities for technological niches to prosper. One example is the global impetus to mitigate and adapt to climate change. The regime level is a socio-technical regime and is the most dominant functioning system. It is composed of prevailing infrastructures, technologies, rules, norms, institutions, industrial networks, markets, and user practices that are characterized as stable and defend the status quo. Lastly, the bottom-tier niche level is composed of so-called "protective spaces" where radical innovations may arise that could challenge the existing regime. One example is the development of renewable energy technologies. At the heart of the interactions and developments between and within each level are actors who have competing claims and interests in the transition [13,14]. 
The MLP has a strong capacity to explain the transition process from a fossil fuel-based energy system to a renewables-based one. It has been used to consider specific types of transition pathways that fit with green or technological innovations by drawing from the experience of developed countries [7,9]. However, it cannot capture the conflicts and coalitionbuilding between and among actors that could affect the transition at the system level because these actors are deemed to be self-interested and to act strategically [14,15].

In addition, applying the MLP to energy transitions in developing countries requires in-depth understanding of the role of a few powerful elites because these countries often have a market system that is not well developed and is controlled by actors that affect transition at the systems level [8]. For example, in Nigeria, powerful political and economic elites who have business stakes in fossil fuels dominate the political and rentier systems [8]. These elites use their market and political power to influence agenda-setting or institutional strategies to favor their interests, even when this means adhering to the status quo [16].

Incorporating the concept of power into an MLP approach enables analysis of the political economic process during a transition. Two basic definitions of power are given in the Oxford English Dictionary: (a) "the ability or capacity to do something or act in a particular way"; and (b) "the capacity or ability to direct or influence the behavior of others or the course of events" [17]. Drawing from this definition, we take the actors and the power they exercise to direct the course of outcomes to their will, as the focal point of our analysis. This research complements the study of Geels [18] on the dynamic interactions between rule-regimes and actors, which shows that different actors have different strengths, power, resources, and opportunities to change the prevailing rules-regime [19].

A typology of power exercise provides tools to analyze how actors play the game to achieve their goals. Power can be defined as innovative, destructive, constitutive, transformative, systemic, or reinforcive [14]. Innovative power is the capacity of actors to create or discover new resources, especially when they cannot gain existing ones. In the process, actors are enabled to become visible to other actors in the system. Conversely, destructive power-the opposite of innovative power-is the ability to destroy or annihilate existing resources. Meanwhile, constitutive power is the ability of actors to formalize the distribution of resources using existing established structures and institutions, thereby enforcing their legitimacy. This is contrary to transformative power, which is defined as the ability of actors to transform the mechanism of resource distribution through the development of new structures and new institutions. Systemic power is the combined ability of actors to mobilize resources towards a collective goal, regardless of whether or not these actors have the consciousness to do so. Lastly, reinforcive power is the capacity of actors to reinforce and reproduce existing structures and 
institutions according to how these actors value and distribute the resources.

With these definitions of power exercise, it is possible to analyze how actors act in a way that could lead them to win or lose the game [19,20]. In this sense, power can be said to always be relational in that an actor exercising power against another could either empower or disempower themselves to gain or lose access, strategies, skills, or willingness to exercise power [19,20].

In line with the above arguments, this paper fills the scholarly gap in studies on the transition from a fossil-based energy system to a renewables-based one by incorporating the concept of power into an MLP to investigate why a developing country goes through an unsustainable energy pathway, taking the Philippines as a case study. We employ an MLP in combination with the concept of power to study the effect of the roles and power exercises of actors in shaping and directing the country's energy transition pathways.

\section{BRIEF HISTORY OF THE PHILIPPINES’ ENERGY TRANSITION}

\section{Challenges in the Philippines' Energy System}

The Philippines has among the highest electricity prices in Asia, at roughly 20 USD per kWh or 10 PHP per kWh [21]. This is higher than some developed countries, such as Japan and Singapore. The Philippines' high electricity price is partly due to the fact that the Philippine government does not provide subsidies to its citizens and that it is expensive to build and maintain the transmission and distribution networks that cover the country's over 7100 islands [22].

As the country's economy and population continue to grow, so too does the demand for energy. The population is already more than 100 million and is growing at an annual rate of $1.72 \%$ [23], and during the Aquino administration from 2010 to 2016 the economy grew at an average annual rate of 6.3\% [24]. Furthermore, the Duterte administration began in 2016 and by its end in 2022, it is projected that the economy will have grown at an average of $6-8 \%$ annually [24].

The country's electricity is primarily obtained from fossil energy sources (coal, oil, and natural gas), which accounted for about $75 \%$ of its total electricity generation in 2017 [25]. Coal supplied the bulk of this, with a $46.6 \%$ share- -46.8 TWh-of the country's total electricity generation; this was $8.2 \%$ higher than in the previous year (2016), when the generation was 43.3 TWh [25]. The next largest energy sources were natural gas (20.5\%) and oil (3.8\%). Most of the coal (88.3\%) was imported from Indonesia, while almost all (99\%) oil imports came from the Middle East [25].

Such a heavy reliance on foreign fossil fuel not only puts the country's energy and financial security at risk, but also makes it harder for it to meet its nationally determined contributions to the Paris Agreement, namely a 
reduction of its greenhouse gas (GHG) emissions by $70 \%$ relative to its business as usual scenario for 2000-30 [26]. Despite this obligation, in 2017 the country's total GHG emissions from energy-related activities increased by $10 \%$ compared with the previous year [25]. Electricity generation contributes the biggest share (49.2\%) of the country's total GHG emissions from energy-related activities, and this share is growing due to the increasing demand for energy [25]. The share of renewables in the country's energy mix has been declining in recent years, decreasing from $40.7 \%$ in 2012 to $21.8 \%$ in 2018 [27,28].

\section{History of Major Landscape Developments and Policy Responses}

There are many regulatory barriers and much opposition to renewables becoming the Philippines' primary source of energy. One such barrier is that the energy policy of the present government focuses on increasing the country's generation capacity at an affordable cost in line with the country's growing economy and population.

Table 1. Key events in the history of the Philippine energy system.

\begin{tabular}{|c|c|}
\hline Year & Events \\
\hline $1890 s$ & Electricity first came in the Philippines \\
\hline 1973 & $\begin{array}{l}\text { The oil crisis led to increased prices of imported energy, decreased foreign concessional loans, and hiked the cost of } \\
\text { borrowing used for the government's electrification program. }\end{array}$ \\
\hline 1976 & $\begin{array}{l}\text { Marcos declared Martial Law and the National Power Corporation (NPC) was made a monopoly owning the } \\
\text { generation and transmission assets as a means to keep electricity prices at bay and pacify public clamor. }\end{array}$ \\
\hline 1986 & $\begin{array}{l}\text { Aquino scrapped most of the previous administration's policies, including the dissolution of the Bataan Nuclear } \\
\text { Power Plant (BNPP) and the Department of Energy (DOE) (replaced by the Office of Energy Affairs) }\end{array}$ \\
\hline 1987 & $\begin{array}{l}\text { Private participation increased with the independent power producers (IPPs), including renewable niches, in the } \\
\text { build-operate-transfer (BOT) and build-own-operate (BOO) arrangements to create new generating capacity, but in } \\
\text { the end they still couldn't keep up with the demand. }\end{array}$ \\
\hline 1993 & $\begin{array}{l}\text { Ramos mandated the Electric Power Crisis Act of } 1993 \text { to fast-tracked energy projects. A new policy called "take-or- } \\
\text { pay” was formulated forcing the distribution utilities to pay for a specified amount of power produced by the } \\
\text { generation companies whether the generated electricity is required or not. }\end{array}$ \\
\hline 1997 & $\begin{array}{l}\text { Peso depreciated in the midst of the Asian financial crisis, resulting into the NPC's contracted IPP payments through } \\
\text { the "take-or-pay" to balloon. }\end{array}$ \\
\hline 2001 & Arroyo mandated the 'Electric Power Industry Reform Act' (or the EPIRA Law) to liberalize the electricity system. \\
\hline 1998-2013 & $\begin{array}{l}\text { The Philippines ratified the Kyoto Protocol. } \\
\text { Several devastating typhoons hit the country most notably: Ketsana, Washi, Bopha and Haiyan, the strongest ever } \\
\text { recorded typhoon that made a landfall. }\end{array}$ \\
\hline 2015 & $\begin{array}{l}\text { The Philippines ratified the Paris Agreement and submitted its INDC pledge to reduce its greenhouse emissions by } \\
70 \% \text { relative its BAU scenario by } 2030 \text {. }\end{array}$ \\
\hline
\end{tabular}

Source: Authors compilations based on sources.

Since the 1970s, at least four major landscape developments have substantially affected the energy regime in the Philippines. The first such development started during the oil crisis in the 1970s that occurred under the Marcos administration. In an attempt to keep electricity prices low 
during the increased fuel prices at that time, Marcos implemented Presidential Directive 40 to make the National Power Corporation (NPC) a state-owned entity, which enabled it to control all the power generation and transmission assets of the country [29]. This move forced private businesses to sell their generating facilities to the NPC. However, poor planning and a weak financial position made the NPC incapable of markedly increasing the country's power generation capacity. Consequently, power supplies became unreliable and load-shedding was frequent. A combined power- and economic crisis eventually ensued [29]. This started with the cancellation of the Bataan Nuclear Power Plant due to heightened fears about the safety of nuclear power following the Chernobyl incident, and continued with the dissolution of the Department of Energy (DOE) during the Aquino administration [30,31]. A rapid growth in the demand for electricity combined with a lack of sufficient generating capacity led to brownouts averaging 7 hours per day in many regions of the country in 1992 and 1993 [32]. This crippled the economy and led to massive unemployment, causing an estimated annual loss of 600-800 million USD, or $1.5 \%$ of GDP [32].

The second landscape development was the Asian financial crisis of 1997. This crisis caused the NPC's contracted independent power producer (IPP) payments to balloon due to the depreciation of the Philippine peso [31,32]. According to Woodhouse [33], this was due to the following reasons: First, as a result of a shortfall in electricity demand at the same time that a significant amount of new power generation capacity came online, the electricity sector entered a period of excessive oversupply in the late 1990s. Constrained by the take-or-pay provisions of the IPP contracts, the NPC began paying higher unit prices for electricity as the dispatch of plants sank to as low as $30-40 \%$. Second, while recovering its IPP payments from a dwindling number of kilowatt hours sold, the NPC also saw its IPP payments substantially increase due to the depreciation of the Philippine peso. These problems led to the NPC accumulating more debts. By 2001, the NPC owed approximately 16.39 billion USD to creditors-consisting of 10.42 billion USD of IPP obligations and 5.97 billion USD of debt-which represented $31.3 \%$ of the country's total external debts at that time [34].

The third landscape development was increased pressure from the World Bank, International Monetary Fund (IMF), and Asian Development Bank (ADB) for the liberalization of the Philippines' energy system. Similar pressure was applied to neighboring countries such as Indonesia and Thailand at that time, which were both pressured to implement structural adjustment agreements such as reforming their power sectors in exchange for external assistance [35]. In 2001, the Arroyo administration signed the Republic Act 9136, also known as the Electric Power Industry Reform Act (EPIRA). This law had two stated primary objectives, namely (i) to secure the country's energy supply, and (ii) to lower its high electricity prices [36]. In line with this, specific provisions were set to (i) disaggregate the 
country's energy industry into generation, transmission, and distribution; (ii) introduce competition in generation and supply; (iii) introduce a wholesale electricity spot market (WESM); (iv) privatize generation and the operation of transmission by a concessionaire; (v) allow open access to distribution networks; and (vi) set up an independent agency to regulate the energy industry [37]. Since the signing of the EPIRA, the Philippines' energy system has been increasingly liberalized. Between 2003 and 2004, the government completed the unbundling of electricity prices; in 2006, the WESM started its operations for the largest electricity consumers in Luzon [37]; and in 2010, the Visayas grid was integrated into the WESM [36]. This latter event was immediately followed by the start of Retail Competition and Open Access, which aims to provide more power to consumers to choose their electricity provider [37]. At present, the Mindanao grid is developing plans to construct a separate WESM [37].

The fourth landscape development was the start of the ongoing global action to combat climate change. Climate change has been implicated in several recent extreme natural disasters in the Philippines. For example, between 1998 and 2013, the country was struck by the most devastating typhoons in its history, which claimed billions of pesos in damaged properties and claimed thousands of lives [38,39]. Most notable among these was Typhoon Haiyan in 2013, which was the strongest typhoon ever recorded in terms of sustained maximum wind speeds [40]. The Philippines ranks 5th out of the 10 countries in the world which were most affected by climate change in terms of annual average between 1998 and 2015 [41]. In part due to the country's vulnerability to natural disasters, the Philippines was one of the first developing countries to sign the Kyoto Protocol, which it did in 1998 [42]. Additionally, in 2015, the country ratified the Paris Agreement and submitted its nationally determined contributions to lower its GHG emissions by $70 \%$ relative to its businessas-usual scenario by 2030. However, despite this, in 2016 the share of renewables in the Philippines' energy mix was only $25 \%$ (10\% geothermal, $10 \%$ hydro, $3 \%$ wind, $1 \%$ solar, and $1 \%$ biomass) [43]. Meanwhile, the share of coal power is currently increasing [43].

\section{Changes in the Energy Mix in Electricity Generation}

Policy responses have led to significant change in the Philippines' energy structure. First, electricity supply has shifted from governmentowned assets to privately owned assets. Second, coal has surpassed renewable energy to become dominant in the energy mix, despite increased renewable energy production. Most of the new coal-powered plants are owned by a private oligopoly (Figure 1A,B). 
(A)

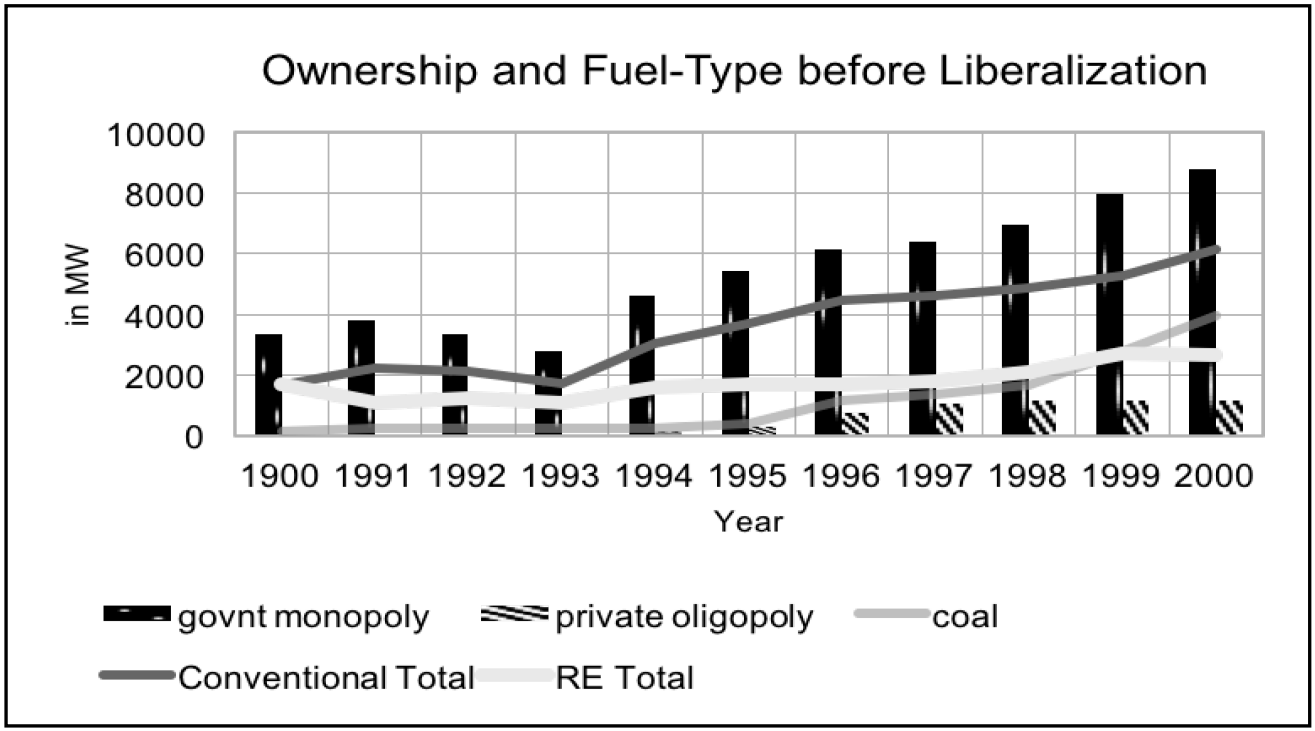

(B)

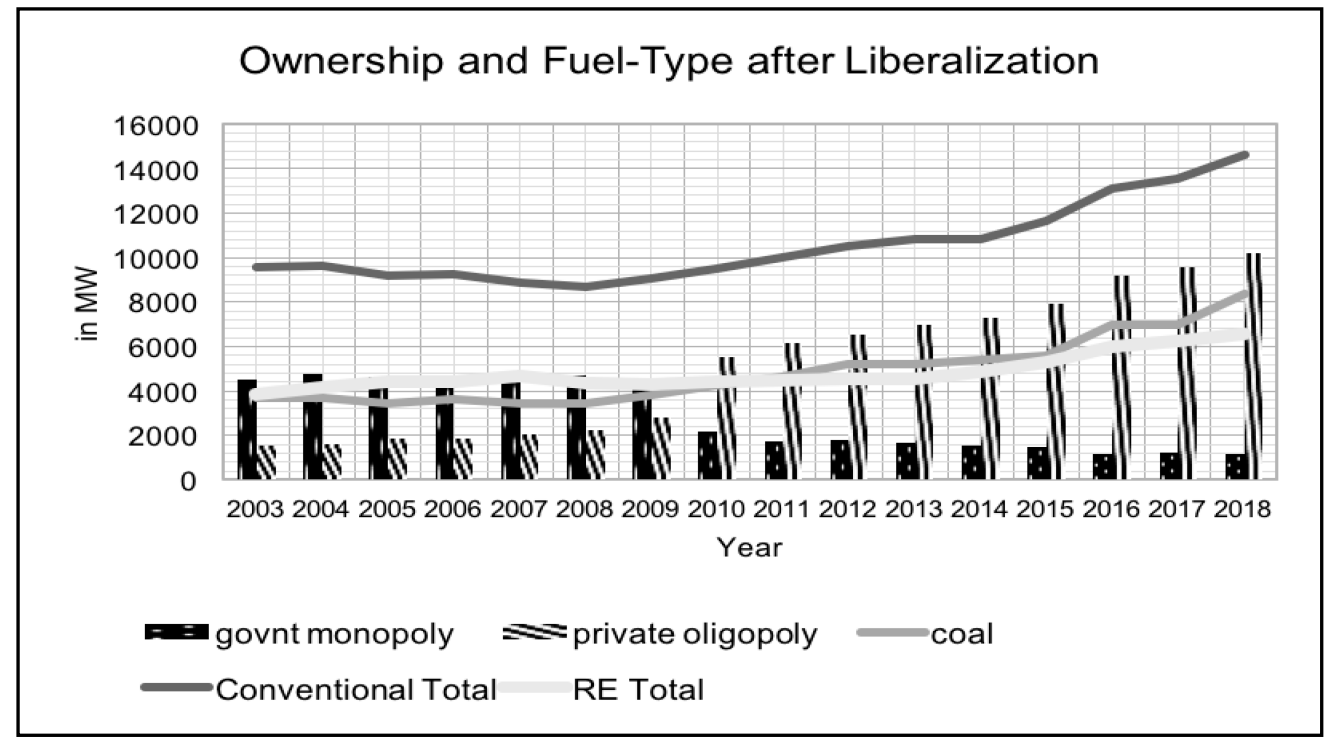

Figure 1. (A) Ownership and Fuel-Type before Liberalization (1990-2000). (B) Ownership and Fuel-Type after Liberalization (2003-2016). Source: Author's calculations based on World Bank's Philippines Power Study, page 17 in 1994 for data on "dependable power capacity" for pre-EPIRA and from the website of the Philippine Department of Energy (DOE) on Power Statistics in 2017 for data on "dependable generating capacity” for post-EPIRA [29,44]. Note that for data on power by ownership (NPC vs. non-NPC), the original figures are in $\mathrm{MwH}$ rather than $\mathrm{MW}$ and is a "gross generation" rather than "dependable generating capacity". To make the data consistent to MW, we assumed full capacity for now thus dividing the current figures to 8760 ( 365 days multiplied to $24 \mathrm{~h}$ ). Although there are still some flaws in the computation, this chart shows a general change on the type of fuel and ownership that happened before and after the implementation of EPIRA Law in 2001 and the implementation of the Renewable Energy (RE) Law in 2011. We will continuously update and correct this flaw as soon as data becomes available.

\section{EXERCISING OF POWER IN THE ENERGY TRANSITION}

\section{Role and Power Exercise of Exogenous Actors}

The role of exogenous actors in the Philippine electricity system started to become more prominent in the 1990s when the country suffered a 
power and economic crisis before liberalization. At this time, multilateral organizations such as the ADB, IMF, and World Bank began to take a more aggressive role in the Philippine energy sector by providing loans, grants, advice, and technical expertise to the Philippine government to restructure its power sector [35]. In 1998, the ADB approved the Power Sector Restructuring Program for 300 million USD, and the Japan Bank for International Cooperation provided a loan of 300 million USD to support the program [45]. The ADB also provided technical assistance to support the restructuring and privatization of the NPC [45]. Moreover, after the government implemented the EPIRA in 2001, the ADB further offered partial credit guarantee through the Power Sector Assets and Liabilities Management (PSALM) corporation and funds to create the WESM [46]. In 1997 and 1998, the IMF and World Bank also provided a rehabilitation loan conditional on privatization and restructuring, which required the privatization of the NPC for its standby credit facility [46]. Currently, foreign investors are exercising a transformative power by funding coal power projects with either one or a combination of direct or bilateral funding, loans, credit guarantees, policy lending, or technical assistance. Two of the top investors are China and Japan, who are both investing in coal projects overseas to expand their already saturated domestic market while strengthening their political ties in developing countries [47]. China and Japan have invested more in overseas coal projects than any other country, and together contributed more than half of the total global financing for coal between 2013 and 2016 (China: 15 billion USD; Japan: 10 billion USD $[48,49])$. The majority of China and Japan's investments for coal projects were in developing countries in South and Southeast Asia, amounting to a total of nearly 20 billion USD between 2013 and 2016; in the same period, China and Japan invested only 4 billion USD in renewable projects [48]. In the Philippines, Japan has exported their coal technology and funded some of the biggest coal projects in the country via major companies such as Toshiba, Tokyo Electric Power Corporation, and Chubu Electric Power. For example, in 2017, a joint venture between Tokyo Electric Power Corporation, Marubeni, and Aboitiz resulted in the expansion of the Pagbilao and Sual plants, which are now estimated to generate a combined $3500 \mathrm{MW}$ of power [49,50]. Meanwhile, between 2010 and 2016, China funded four coal projects totaling $2000 \mathrm{MW}$, and the country is currently developing several coal projects, including a $1500 \mathrm{MW}$ project by the China Energy Development Corporation [51,52].

This is not to say that these foreign countries are not investing in renewables. Countries such as China, Japan, and the United States are driven by their own commitments to the Paris Agreement, the increasing awareness of climate change, and the declining cost of renewable energy technologies worldwide, and have invested heavily in their domestic renewable energy industries. These three countries contributed almost half of the total global investments in renewable energy made between 2013 and $2016[3,48]$. Although these countries seem committed to 
investing in renewable energy at the domestic level, they are supporting coal power abroad. Multilateral banks including the World Bank, ADB, African Development Bank, and European Bank for Reconstruction and Development used to do the same; however, a lawsuit against the International Finance Corporation discouraged these multilateral banks from exercising transformative power, and in 2013 they publicly announced that they would support and finance the development of more sustainable energy resources and would fund coal only in rare and exceptional circumstances [53].

\section{Government's Power Exercise in Policy Making Process}

Learning from the experience of the subsequent oil and financial crisis on the economy and on political approval of the present regime, the government has attempted to achieve a stable energy supply and cheaper electricity rates to a growing economy and population by promoting coal as the main source of energy. This echoes the statement of the current Secretary of Energy, Alfonso Cusi, that "coal-fired [power plants] are more dependable and more reliable sources of power than renewable energy alone. "As a developing country, we can't afford not to have coal. You find that balance-the energy mix cannot all be renewable energy. I'm not against solar and the other renewables, and I'd like to promote it some other way" [54]. By using so-called "clean coal" technologies (CCTs), the Philippine government is able to defend the continued building of coal power plants [55] by promoting the adoption of "high efficiency supercritical coal-power technology". This technology is said to be more efficient and burns less coal than the traditional sub-critical power plants that are mostly operating in the country at present [55]. Ironically, China, the U.S and even Japan, as among the largest investors of coal projects worldwide are primarily exporting its subcritical coal technologies instead to these emerging economies of Asia including the Philippines [56,57]. Plus, even this high efficient coal technology still emits $\mathrm{CO} 2$ and runs counter to the global aim of reducing the global temperature to a maximum 2 degrees Celsius.

As a result of the ongoing drive for coal power, the Philippines' coal production and consumption are estimated to increase fivefold by 2040, despite the country's modest domestic coal reserves [55]. The Semirara Mining Company (a subsidiary of DMCI, Inc.) is the largest producer of coal in the Philippines; however, most of its output that is exported as domestic plants cannot use the lower-grade coal it produces [25]. In December 2011 alone, the DOE offered 30 new operating contracts to expand coal mining exploration and operations in the Visayas and Mindanao regions in an attempt to double domestic coal production by 2030 [55]. Furthermore, between 2018 and 2019, the DOE announced a combined new power generation capacity of around $5688 \mathrm{MW}$, at least $63 \%$ of which will come from coal-fired power plants [21]. 
To attract investment in the coal sector, the current government is exercising a transformative power by implementing policies such as the "automatic pass-through", which creates secure profit and protects businesses against volatility risks in fuel prices and foreign exchange rates [46,58]; this policy essentially allows energy companies to pass the financial burden and investment risks caused by such volatility to consumers [58], thereby making coal the most secure and preferred energy choice for energy companies and investors [46,58].

However, the government also exercises its constitutive power for the deployment of renewable energy on two grounds: the variability of its supply, and its high investment costs [59,60]. Although the previous regime legislated a renewable energy law that aimed to implement the Feed-in Tariff (FiT) program in 2008, it took 4 years to implement its guidelines and rates. The "first come first to commercialize" policy requires project developers to construct the renewable facility and pass specific criteria before they can qualify for the FiT incentive [61], thereby imposing high upfront costs on the developers; consequently, despite the government defending the "first come first to commercialize" policy as a strategy to deter speculators, it has had the effect of inhibiting the development of renewables. Additionally, the planned introduction of the "FiT Allowance" (FiT-All), a uniform monthly deduction from the electricity bills of consumers to fund the FiT program, has suffered from many delays. In determining the FiT-All, Transco, as the collector for this fund, is required to submit its FiT-All application to the Energy Regulatory Commission, who then decides and approves its rates. The FiT-All for the following year must be determined and approved by the ERC each year no later than 31 October . However, for the 2018 FiT-All application, Transco was a month behind schedule to submit its application, and the Energy Regulatory Commission had still not approved the its rates as of August 2018, almost a year passed the deadline [62].

At the local institutional level, the local government exercises its constitutive power by a complex permitting process that slows down (potentially by months) and increases the costs of renewable energy development. For example, building a $3 \mathrm{~kW}$ retrofit solar power facility in the Philippines is estimated to cost 56,840 PHP, equivalent to $11 \%$ of total project costs, and takes 28 man-days to complete [63,64]. The delays caused by the permitting process can be especially large when renewable energy developers have to obtain permission from Local Government Units (LGUs) and/or indigenous peoples (IPs). For example, the developers may be required to secure a permit from the National Commission for Indigenous Peoples when the land that they wish to build on is within the ancestral domain of an IP [63,64]. To obtain the land permit, the developers must consult and receive the signatures of the chieftains of the IP. Furthermore, LGUs may also have powers that allow them to overrule national directives, particularly those pertaining to the issuing of permits and 
licenses, and this can sometimes perpetuate bribery and corruption at the local level $[6,63,64]$.

\section{Emergence of Energy Oligarchs and Their Power Exercise}

The Philippine energy system is moderately concentrated yet within the $30 \%$ limit set by the EPIRA Law [65] (Section 45 of the EPIRA states that "a company/person or related group is allowed to supply energy demand to a maximum of $30 \%$ of the installed generation capacity of a grid (e.g., Luzon grid) and $25 \%$ of the national installed generating capacity."). The San Miguel Corporation (SMC), the Aboitiz Group, and the First Gen Corporation (FGC) currently command the largest shares of the total produced energy in the country (SMC, 20\%; FGEN, 17\%; Aboitiz, 16\%) [65]. These companies are the three largest companies in the Philippines, and own businesses in a wide range of markets, such as telecommunications, food and beverage, and real estate. Furthermore, these companies have longstanding familial histories of wealth and power tracing back to the times of Spanish and United States colonial rule. As McCoy (2009: xi) writes, "the Filipino oligarchy has survived from generation to generation, amassing ever greater wealth and power with every twist in this tangled national history" [66]. These companies grew in power and replaced the government as the main suppliers of energy in the Philippines beginning around the time of liberalization in the 1990s, when PSALM began to sell its government assets and contracts. These 3 companies together with other 7 energy oligarchs command more than $70 \%$ market share of power generated in the country [65]. Meanwhile, the government-owned PSALM and NPC have only a $13 \%$ combined market share in the total produced energy in the country, and all the other IPPs have only a combined 15\% market share [65,67].

Although SMC entered the power industry only in 2008, SMC is now the largest single supplier of energy in the Philippines [68,69]. SMC supplies about $20 \%$ of the total fossil energy (i.e., coal, oil, and natural gas) used in the country, of which $60 \%$ comes from coal (Table 2). As of 2017, it had no small-scale renewable energy generation plants in its energy portfolio. The second-largest supplier of energy, Aboitiz Power, has been in the energy business for a long time [70]. As of 2017, its generated energy came from mainly fossil energies, contributing roughly $10.6 \%$ of the fossil energy consumed in the Philippines. The renewables in Aboitiz Power's energy portfolio are mostly large geothermal and large hydropower projects commanding $25.5 \%$ of the total market share. The company only began to include small-scale renewables (e.g., solar and biomass) in its energy portfolio in 2016. Currently, Aboitiz Power contributes around $1.5 \%$ of the total renewable energy produced in the Philippines. Meanwhile, the Lopez Holdings Corporation via FGEN is the controlling shareholder of the Energy Development Corporation, which is partly owned by the government and the largest producer of geothermal energy in the world 
[71,72]. Therefore, of the three aforementioned companies, the Lopez Holdings Corporation has the "greenest" energy portfolio.

Our findings suggest that energy oligarchs in the Philippines can be classified into incumbents and newcomers. The incumbents-namely Aboitiz and the Energy Development Corporation (EDC)-have a significant proportion of large geothermal and hydropower in their generation capacity, whereas the newcomers-namely SMC and First Gen, Inc.-contain mostly coal power in their energy portfolios (Table 2). However, regardless of the differences in their energy portfolios, these oligarchs have capitalized on the capital of both external actors and technology provision, and on governmental liberalization and coalfavoring policies to expand their coal power generation capacity. As these companies have become dominant in the Philippines' energy market, so has coal become dominant in its energy mix.

Table 2. Energy by type owned by the energy oligarchs, as of June 2017.

\begin{tabular}{|c|c|c|c|c|c|}
\hline Company & $\begin{array}{c}\text { Total installed } \\
\text { capacity (in MW) }\end{array}$ & $\begin{array}{c}\text { Fossils } \\
\text { (in MW) }\end{array}$ & Coal (in MW) & $\begin{array}{c}\text { Geothermal } \\
\text { Hydro (in MW) }\end{array}$ & $\begin{array}{c}\text { Small RE (solar, wind, run- } \\
\text { of-rive hydro, biomass) (in } \\
\text { MW) }\end{array}$ \\
\hline SMC (San Miguel) & 3586.0 & 2905.0 & 1734 & 681.0 & 0 \\
\hline Aboitiz (Aboitiz) & 2998.8 & 1558.6 & 951.6 & 1416.8 & 23.4 \\
\hline FGEN (Lopez) & 2297.5 & 2163.9 & $\sim 2163.9$ & 133.6 & 114.6 \\
\hline $\begin{array}{c}\text { EDC (majority Lopez, } \\
\text { partly government) }\end{array}$ & 1271.4 & 0 & $\begin{array}{c}\text { cannot be } \\
\text { determined }\end{array}$ & 156.8 \\
\hline Government's PSALM & 284.1 & 921.9 & 232 & 509.1 & 0 \\
\hline TOTAL & $13,037.80$ & 749.40 & 217.6 & 180.2 \\
\hline
\end{tabular}

Source: Authors' calculation based on the data from DOE on Existing Power Plants as of June 2017 [44]. Note that the data is installed capacity in MW. Fossils refer to the aggregate total of coal, oil-based and natural gas. It should be noted that these figures are just conservative estimates given that some companies have partnerships or co-ownership of these power plants. Thus, the authors only could consider the power plants that these companies have 'direct ownership'. Also, excluded here are the power plants in off-grid areas. The merit of showing this table is to show a rough estimate of the energy portfolio of these companies to see which type of energy they are mostly investing.

The cross-ownership provision in the EPIRA further discourages prospective investors from investing in renewable energy. The crossownership clause allows a distribution company to source "only $50 \%$ of its total energy demand" from its affiliate company. Meralco, the largest electricity distribution company in the Philippines, commands a 70\% market share in Luzon and about a 55\% market share in the country as a whole [73]. (It should be noted that SMC has a $43 \%$ business stake in Meralco [74].) Meralco generates energy via its subsidiary, Meralco Power Generation [75]. Meralco Power Generation's energy portfolio consists of coal and natural gas, and the company is aiming to increase its total combined installed capacity of coal and natural gas to $3000 \mathrm{MW}$ by 2020 [75]. It also has bilateral contracts with Aboitiz Power. Aboitiz Power has at least one energy distribution subsidiary on all of the three major islands 
and archipelagos of the Philippines-Subic and Lima Enerzone on Luzon, the Visayan Electric Co. in the Visayas, and the Davao Light Company on Mindanao [76] - and these subsidiaries have been criticized for blocking small stand-alone generating plants from attracting a buyer because they prefer obtaining power from an affiliate generating company (e.g., owned by the energy oligarchs) [31].

\section{IMPLICATIONS FOR THE DEPLOYMENT OF RENEWABLE ENERGY}

Figure 2 summarizes the results of our analysis of the relations and exercising of power between actors in the Philippine energy system.

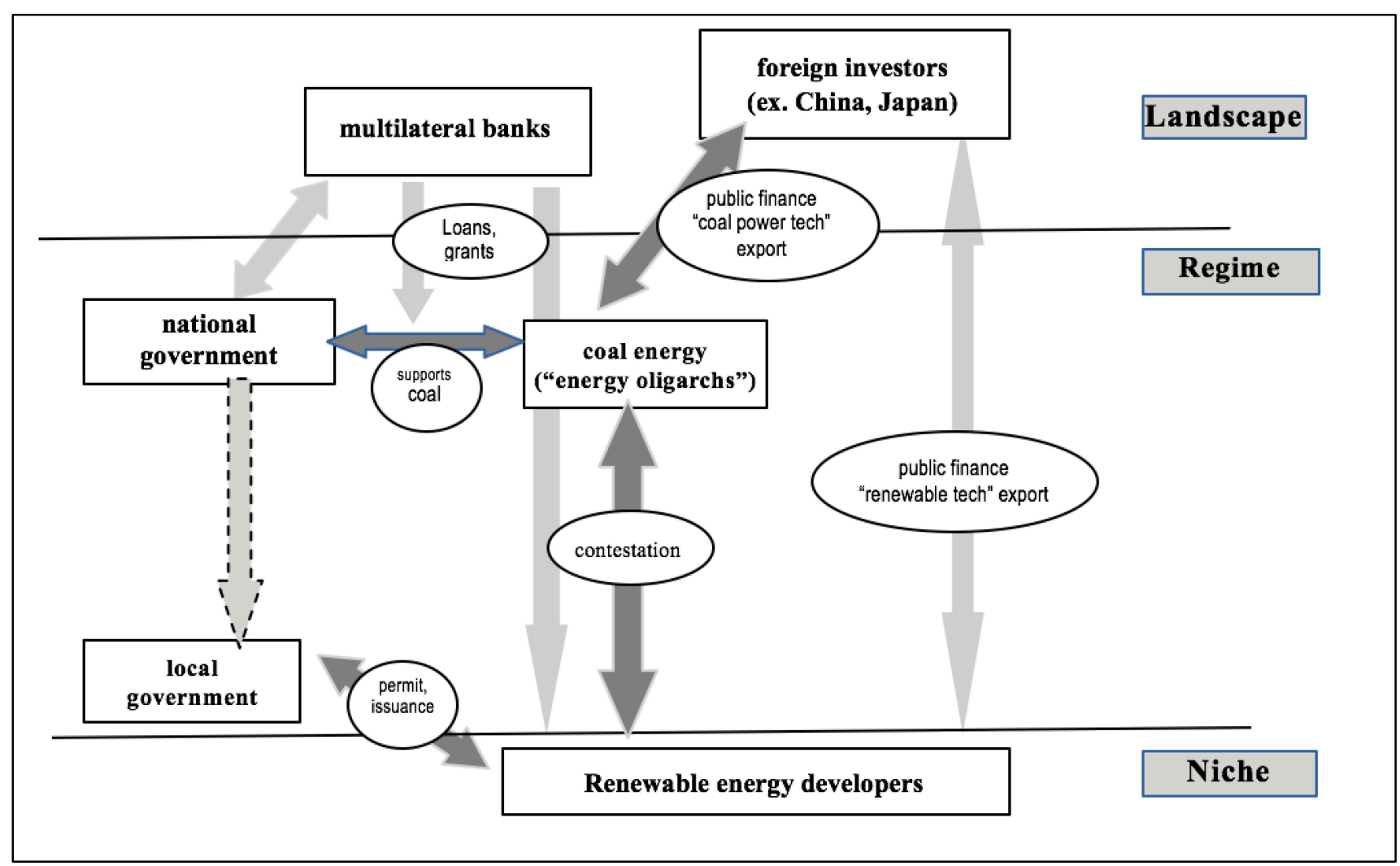

Figure 2. Role and power relation among actors. Source: Authors' illustration. This is a simple illustration summarizing the relations and power exercise between and among actors in the Philippine energy system. The dark-shaded arrow shows a direct link while the light-shaded arrow shows a weaker link between these actors. The broken arrow between the national and the local government shows that in theory the LGU is under and must follow the national government policies and directives on renewable energy but in practice, due to the disconnect and weak coordination between them, the LGUs can rule these policies and directives out and implement their own.

The landscape developments during the severe economic and power crises in the 1990s forced the government to place energy security and affordability as top priorities without envisioning the longer-term sustainability of the energy mix; due to the cheapness and stability of supply of coal, the government exercised its constructive power to formalize its position in the country's energy mix while promoting renewables only as an "add-on" to existing energy sources. 
Power producers and foreign investors took advantage of the government's prioritization of energy security and affordability by positioning themselves to supply the Philippines' energy demand with coal power. The "energy oligarchs" who grew to dominate the country's energy system-partly due to the certain flaws in the provisions of the EPIRAare now the biggest coal producers in the country. In brief, we find that the liberalized energy system provided these large producers with a reinforcive power given that they had the resources to (1) buy energy assets from the government during its privatization, (2) construct power plants (mostly coal plants), which could help meet the priority of the government to ensure a stable supply of energy, and (3) purchase affiliate companies in all electricity sub-sectors, thereby expanding the extent of their power. Meanwhile, foreign investors, mainly from China and Japan, are investing in coal projects abroad as a means to strengthen their political ties and find alternatives to their dwindling domestic demand for coal. Although such countries are investing in renewables domestically, they are prioritizing coal in their overseas energy investments.

The results of this study have two implications for energy transitions in developing countries. First, the liberalization of the electricity market does not necessarily create a level playing field, and may merely result in a shift in the dominant power structure from a government monopoly to a private oligopoly. Second, unless the government perceives renewable energy as a proven, competitive technology that can provide a stable and affordable energy supply, coal becomes the dominant source of electricity supply. In the past, energy crises have proved to be a source of political instability that could end the term of a sitting president. Developing countries with both a promising economic potential and a growing population, such as the Philippines, may prioritize the increase of their electricity generation capacity over sustainability, even though they recognize and have experienced the impacts of climate change.

\section{CONCLUSIONS}

A shift toward a sustainable energy system is greatly facilitated when renewable energy technologies become much more appealing energy options. However, political factors deter many developing countries from deploying renewable energy. This paper aimed to elucidate how exogenous actors and regime incumbents exercise power to block the emergence of renewables in developing countries, using the Philippines as a case study. By combining the MLP with an analysis of power exercises, we found that three types of power exercises have moved the Philippines toward a coal-based energy system.

First, multilateral banks and foreign investors can exercise transformative power to pressure the government towards liberalizing the energy system, and these actors are currently supporting both coal and renewables. They may provide capital and technologies for coal power, and to a lesser extent and more indirectly for renewable energy. Second, 
"energy oligarchs" can exercise reinforcive power to reproduce and create a new private oligopolistic energy structure by acquiring energy assets, building coal power plants, and dominating energy supply chains. Lastly, the government can exercise constitutive and transformative power to induce foreign investors and energy oligarchs to continue to invest in coal power. Coupled with the governmental exercising of constitutive power that makes FiT incentives difficult to obtain and administrative red tape, these power exercises and their interplay are more likely to hinder the deployment of renewable energy technologies.

The Philippine case study suggests that in developing countries the liberalization of the electricity market may merely result in a shift in the dominant power structure from a government monopoly to a private oligopoly and thereby lead to the transition toward a coal-based energy system. This trajectory is unlikely to change unless the government perceives renewable energy as a proven, competitive technology that meets its energy goal of a stable and affordable energy supply.

\section{AUTHOR CONTRIBUTIONS}

PS and AM conceived and designed the study. PS performed the field survey and interviews, processed these experimental data to draft the initial manuscript. AM encouraged PS to investigate and further explore the analysis, as well as revised the manuscript to strengthen the analysis by himself. Both authors discussed the results and contributed to the final manuscript.

\section{CONFLICTS OF INTEREST}

The authors declare that there is no conflict of interest.

\section{FUNDING}

This work was supported by JSPS Research Grant 26285041 and $18 \mathrm{H} 03426$.

\section{ACKNOWLEDGMENTS}

The authors are grateful to their colleagues for their valuable comments in improving the contents of the paper. Special thanks to Director Mario Marasigan, Director of the Renewable Energy Management Bureau (REMB) and his staff, and to all the students in the Global Environmental Economics group under the Graduate School of Global Environmental Studies (GSGES), Kyoto University.

\section{REFERENCES}

1. REN21. Renewables 2017 \& 2018 Global Status Report. 2017 \& 2019 reports. Available from: https://www.ren21.net. Accessed 2019 Aug 17. 
2. Saculsan P, Mori A. What Can the Philippines Learn from Thailand's ENCON Fund in Overcoming the Barriers to Developing Renewable Energy Resources. J Clean Energy Technol. 2018;6(4):278-83. https://doi.org/10.18178/JOCET.2018.6.4.474

3. Bloomberg New Energy Finance. Clean energy investment in emerging markets. 2017. Available from: https://about.bnef.com/blog/clean-energyinvestment-emerging-markets/. Accessed 2018 Jun 24.

4. Geels FW. Technological transitions as evolutionary reconfiguration processes: a multi-level perspective and a case-study. Res Policy. 2002;31:1257-74. https://doi.org/10.1016/S0048-7333(02)00062-8

5. Markard J, Hoffmann VH. Analysis of complementarities: Framework and examples from the energy transitions. Technol Forecast Soc Change. 2016;111:63-75. http://dx.doi.org/10.1016/j.techfore.2016.06.008

6. Marquardt J. How power affects policy implementation: Lessons from the Philippines. J Curr Southeast Asian Aff. 2017;36(1):3-27. https://doi.org/10.1177/186810341703600101

7. Mori A. Temporal dynamics of infrasystem transition: The case of electricity system transition in Japan. Technol Forecast Soc Chang. 2019;145:186-94. https://doi.org/10.1016/j.techfore.2017.05.003

8. Osunmuyiwa O, Biermann F, Kalfagianni A. Applying the multi-level perspective on socio-technical transitions to rentier states: the case of renewable energy transitions in Nigeria. J Environ Policy Plan. 2017;20(2):143-56. https://doi.org/10.1080/1523908X.2017.1343134

9. Geels FW. Regime Resistance against Low-carbon transitions: Introducing Politics and Power into the Multi-Level Perspective. Theory Culture Soc. 2014;31(5):21-40. https://doi.org/10.1177/0263276414531627

10. Unruh GC. Understanding carbon lock-in. Energy Policy. 2000;28:817-30.

11. Verbong GPJ, Loorbach D. Introduction. In: Verbong GPJ, Loorbach D, editors. Governing the Energy transitions: Reality, Illusion or Necessity? Oxford (UK): Routledge; 2012. p. 1-23

12. Geels F, Schot J. Typology of sociotechnical transition pathways. Res Policy. 2007;36(3):399-417. https://doi.org/10.1016/j.respol.2007.01.003

13. Könnölä T, Carrillo-Hermosilla J, van der Have RP. System TransitionConcepts and Framework for Analyzing Nordic Energy System Research and Governance. VTT Technical Research Centre of Finland Working Papers 99. Espoo (Finland): VTT Technical Research Centre of Finland; 2008 May. http://dx.doi.org/10.2139/ssrn.1140141

14. Avelino F, Rotmans J. Power in transition: An interdisciplinary framework to study power in relation to structural change. Eur J Soc Theory. 2009;12(4):54369. https://doi.org/10.1177/1368431009349830

15. Smith A, Voß J-P, Grin J. Innovation studies and sustainability transitions: The allure of the multi-level perspective and its challenges. Res Policy. 2010;39(4):435-48. https://doi.org/10.1016/j.respol.2010.01.023

16. Avelino F, Wittmayer J. Shifting Power Relations in Sustainability Transitions: A Multi-actor Perspective. J Environ Policy Plan. 2015;18(5):628-49. https://doi.org/10.1080/1523908X.2015.1112259 
17. Oxford Dictionary. Power (definition). Available from: https://www.lexico.com/en/definition/power. Accessed 2017 Nov 20.

18. Geels FW. From sectoral systems of innovation to socio-technical systems: Insights about dynamics and change from sociology and institutional theory. Res Policy. 2004;33(6-7):897-920. https://doi.org/10.1016/j.respol.2004.01.015

19. Avelino F. Power in Transition: Empowering Discourses on Sustainability Transitions. Rotterdam (the Netherlands): Erasmus University Rotterdam; 2011 Dec 9. Available from: http://hdl.handle.net/1765/30663. Accessed 2018 Sep 22.

20. Avelino F. Power in Sustainability Transitions: Analyzing power and (dis) empowerment in transformative change towards sustainability. Environ Policy Govern. 2017;27(6):505-20. https://doi.org/10.1002/eet.1777

21. Ahmed SJ. The Philippine energy transition: Building a robust power market to attract investment, reduce prices, improve efficiency and reliability. Cleveland (OH, US): Institute for Energy Economics and Financial Analysis. 2019 March. Available from: http://ieefa.org/wp-content/uploads/2019/03/ThePhilippine-Energy-Transition_March-2019.pdf. Accessed 2019 Nov 2.

22. Kim R, Kapstein E. Economic Impact of IFI Investments in Power Generation in the Philippines. Haarlem (the Netherlands): Steward Redqueen; 2015. Available from: https://jobsanddevelopment.org/wpcontent/uploads/2018/04/Report-IFC-Philippines-power-project.pdf. Accessed 2019 Aug 23.

23. Philippine Statistics Authority. Philippine Population Surpassed the 100 Million Mark (Results from the 2015 Census of Population). Available from: https://psa.gov.ph/content/philippine-population-surpassed-100-millionmark-results-2015-census-population. Accessed 2019 Jun 22.

24. Verzola S, Logarta L Jr, Maniego P Jr. Towards a Just Transition in the Philippine Electricity Sector: Challenges and Opportunities. Berlin (Germany): Friedrich-Ebert-Stiftung (FES); 2018. Available from: https://www.fesasia.org/news/towards-a-just-transition-in-the-philippine-electricity-sector/. Accessed 2019 May 28.

25. Philippine Department of Energy (DOE). Power Situation. 2015. Available from: $\quad$ https://www.doe.gov.ph/electric-power/2015-philippine-powersituation. Accessed 2017 Dec 24.

26. Ranada P. Philippines commits to reduce carbon emissions by $70 \%$. Rappler. 2015 Oct 1. Available from: https://www.rappler.com/sciencenature/environment/107759-philippines-indc-climate-change-united-nations. Accessed 2019 May 11.

27. Saulon VV. Coal plants' share in 2017 energy mix expands to over 35\%. Business World. 2018 Mar 4. Available from: http://bworldonline.com/coalplants-share-2017-energy-mix-expands-35/. Accessed 2019 May 20.

28. Department of Energy (DOE). Philippine Energy Plan (2012-2030). Available from: $\quad$ https://www.doe.gov.ph/pep/philippine-energy-plan-2012-2030. Accessed 2019 May 24.

29. World Bank. Philippines-Power sector study: structural framework for the power sector. Washington DC (US): World Bank; 1994 Nov 30. Available from: 
http://documents.worldbank.org/curated/en/147831468759282455/pdf/multipage.pdf. Accessed 2018 Feb 3.

30. Navarro AM, Detros KC, dela Cruz KJ. Post-EPIRA Impacts of Electric Power Industry Competition Policies. Quezon City (Philippines): Philippine Institute for Development Studies; 2016 May. Discussion Paper No. 2016-15. Available from: https://pdfs.semanticscholar.org/68e8/11ad920b90d1957ce0ffb3d5f9f5e 24e5f4e.pdf. Accessed 2019 Jul 26.

31. Chavez-Malaluan JJ. Competing interest in the reform process: the case of the Philippine power sector restructuring. Manila: Focus on the Global South. Pune (India): Prayas; 1987. Available from: https://www.prayaspune.org/. Accessed 2018 Aug 5.

32. Pormon M. Alleged Collusion Effects in Power Supply Shortage in the Philippines. Tacloban (Philippines): University of the Philippines-Visayas Tacloban College; 2017. Available from: http://kea.ne.kr/conference2017/download/S3-8-2_Miah\%20Pormon.pdf. Accessed 2019 Nov 2.

33. Woodhouse E. Political economy of international infrastructure contracting, lessons from IPP experience, working paper for Program on Energy and Sustainable Development. Working Paper No. 52. Stanford (CA, US): Program on Energy and Sustainable Development; 2005 Sep 30. Available from: https://fsi-live.s3.us-west-1.amazonaws.com/s3fs-public/PESD IPP Study\%2C Global Report.pdf. Accessed 2019 Nov 5.

34. Antonio HD. A history of the Philippine power sector in The Energy Report Philippines: Growth and Opportunities in the Philippine Electric Power Sector. 2013-2014 ed. Manila (Philippines): KPMG Global Energy Institute; 2013. Available from: $\quad$ https://home.kpmg/content/dam/kpmg/ph/pdf/ InvestmentGuide/2013PHInvestmentGuideInvestmentGuideTheEnergyRepo rtPhilippines.pdf. Accessed 2018 Mar 15.

35. Sulistiyanto P, Wu X. The Political Economy of Power Sector Restructuring in Southeast Asia. Paper presented at Conference on Regulation, Deregulation and Re-regulation in Globalizing Asia, Public Policy Programme; 2004 Mar 2224; National University of Singapore, Singapore. Available from: http://citeseerx.ist.psu.edu/viewdoc/download?doi=10.1.1.198.8652\&rep=rep $1 \&$ type=pdf. Accessed 2019 Jul 26.

36. Philippine Department of Energy (DOE). Republic Act 9136, or the EPIRA Law. Manila (Philippines): DOE; 2001. Available from: https://www.doe.gov.ph/laws-and-issuances/republic-act-no-9136. Accessed 2019 May 20.

37. Asian Development Bank (ADB). Performance Evaluation Report: Philippines: Electricity market and transmission project. Manila (Philippines): ADB. 2016. Available from: https://www.adb.org/sites/default/files/evaluationdocument/167391/files/pper-phi-electricity-market.pdf. Accessed 2017 Dec 28.

38. Weather Philippines. Strongest Typhoons in the Philippines. Weather Philippines. 2018. Available from: https://weatherph.org/strongest-typhoonsphilippines/. Accessed 2019 May 29. 
39. Padua D. Deadliest typhoons in the PH. Rappler. 2014 Jul 10. Available from: https://www.rappler.com/nation/43218-deadliest-typhoons-ph. Accessed 2019 May 29.

40. Bradsher K. Philippines is haunted by chaos of earlier storm as typhoon Mangkhut hits. New York Times. 2018 Sep 14. Available from: https://www.nytimes.com/2018/09/14/world/asia/typhoon-mangkhutphilippines-haiyan.html. Accessed 2019 May 29.

41. Eckstein D, Hutfils MA, Winges M. Global Climate Risk Index 2019. A research study by Germanwatch. 2019 Dec 10. Available from: https://germanwatch.org/en/cri. Accessed 2019 Jun 10.

42. Paculdar A, Parreño M. The Philippines' response to climate change. Asia Research News. 2008 Oct 15. Available from: https://www.innovationsreport.com/html/reports/environment-sciences/philippines-responseclimate-change-120282.html. Accessed 2019 May 27.

43. Philippine Department of Energy (DOE). 2016 Philippine Power Statistics. Manila (Philippines): DOE; 2016. Available from: https://www.doe.gov.ph/philippine-power-statistics. Accessed 2017 Jun 23.

44. Philippine Department of Energy (DOE). 2017 Power Statistics. Manila (Philippines): DOE, 2017. Available from: https://www.doe.gov.ph/philippinepower-statistics. Accessed 2018 Feb 3

45. Asian Development Bank (ADB). Report and recommendation on a proposed loan and technical assistance grants to the Republic of the Philippines for the power sector restructuring program. Manila (Philippines): ADB; 1998. Available from: $\quad$ https://www.adb.org/sites/default/files/projectdocument/72245/rrp-r21098c1.pdf. Accessed 2017 Dec 20.

46. Freedom from Debt Coalition (FDC). Philippine power fact sheet. 2007. Available from: $\quad$ https://pcij.org/blog/wp-docs/Philippine Power Fact Sheet.pdf. Accessed 2019 May 2.

47. Baruya P. International finance for coal-fired power plants. London (UK): IEA Clean Coal Centre; 2017. Available from: https://www.usea.org/sites/default/files/International\%20finance\%20for\%20 coal\%20fired\%20power\%20plants\%20-\%20ccc277.pdf. Accessed 2019 Oct 19.

48. Chen H, Schmidt J. Power shift: Shifting G20 international public finance from coal to renewables. Natural Resources Defense Council (NRDC) report. New York (NY, US): NRDC; 2017. Available from: https://www.nrdc.org/resources/power-shift-g20-international-publicfinance-from-coal-to-renewables. Accessed 2019 Oct 10.

49. Karunugan RJ. Japan's dirty coal in PH. Rappler. 2015 Oct 24. Available from: https://www.rappler.com/move-ph/issues/disasters/110384-japan-dirty-coalfinance-philippines. Accessed 2020 Jan 17.

50. How a Japanese company is contributing to a nation's progress. Inquirer. 2017 Jun 22. Available from: https://business.inquirer.net/231773/japanesecompany-contributing-nations-progress. Accessed 2020 Jan 17.

51. Herve-Mignucci M, Wang X. Slowing the Growth of Coal Power Outside China: The Role of Chinese Finance. A Climate Policy Initiative (CPI) report. San Francisco (US): CPI; 2015. Available from: 
https://climatepolicyinitiative.org/publication/slowing-the-growth-of-coalpower-outside-china-the-role-of-chinese-finance/. Accessed 2020 Jan 13.

52. Gonzales D. China to put up merchant power plants in $\mathrm{PH}$ to help build power capacity-Cusi. Philippine Daily Inquirer. 2019 May 2. Available from: https://globalnation.inquirer.net/175091/china-to-put-up-merchant-powerplants-in-ph-to-help-build-power-capacity-cusi. Accessed 2020 Jan 10.

53. Roasa D. Broken promises: The World Bank, international investors and the fight for climate justice in the Philippines (report). Asheville (NC, US), Amsterdam (the Netherlands), Quezon City (Philippines): Inclusive Development International, Bank Information Centre Europe and Philippine Movement for Climate Justice; 2018 April. Available from: https://biceurope.org/wp-content/uploads/2018/04/Broken-Promises-The-World-BankInternational-Investors-and-the-Fight-for-Climate.pdf. Accessed 2019 Aug 2.

54. Remo A. Coal to remain big part of energy mix. Philippine Daily Inquirer. 2016 Jul 5. Available from: http://business.inquirer.net/211635/coal-remain-bigpart-energy-mix. Accessed 2017 Nov 3.

55. Kessels J, Baruya P. Prospects for coal and clean coal technologies in the Philippines. London (UK): IEA Clean Coal Centre; 2013. Available from: https://www.usea.org/sites/default/files/032013 Prospects\%20for\%20coal\%20 and \%20clean\%20coal\%20technology\%20in\%20the\%20Philippines ccc $217 . p$ df. Accessed 2019 Aug 26.

56. Ueno T, Yanagi M, Nakano J. Quantifying Chinese Public Financing for Foreign Coal Power Plants. GraSPP (The Graduate School of Public Policy, University of Tokyo) Discussion Paper E-14-003. Tokyo (Japan): GraSPP; 2014 Nov. Available from: http://www.pp.u-tokyo.ac.jp/wp-content/uploads/2016/03/ GraSPP-DP-E-14-003.pdf. Accessed 2020 Jan 10.

57. Tanabe Y. Do JBIC funded coal plants really have highly efficient, clean technology? Presented at International Symposium on Climate Change and Coal. Tokyo (Japan): Japan Center for a Sustainable Environment and Society (JACSES); 2015 May 29. Available from: https://sekitan.jp/wpcontent/uploads/2015/06/Part2-discussion Tanabe-EG.pdf. Accessed 2019 Oct 10.

58. Ahmed SJ. Prospect Improve for Energy Transition in the Philippines: More transparent bidding, pricing and risk avoidance gaining ground. Cleveland (OH, US): Institute for Energy and Financial Economics (IEEFA); 2019. p. 1-29. Available from: https://ieefa.org/wp-content/uploads/2019/09/ProspectsImprove-for-Energy-Transition-in-the-Philippines September-2019.pdf. Accessed 2019 Oct 15.

59. International Renewable Energy Agency (IRENA). Renewables Readiness Assessment: The Philippines. Abu Dhabi (United Arab Emirates): IRENA; 2017 Available from: https://www.irena.org/-/media/Files/IRENA/Agency/ Publication/2017/Mar/IRENA RRA Philippines 2017.pdf. Accessed 2019 Jun 19.

60. Rosellon MA. The renewable energy policy debate in the Philippine. Manila (Philippines): Philippine Institute for Development Studies (PIDS); 2017. PIDS 
Discussion Paper Series, No. 2017-17. Available from: https://www.econstor.eu/handle/10419/173594. Accessed 2017 Sep 3.

61. Remo A. First come first served policy for RE projects. Philippine Daily Inquirer. $2013 \quad$ Feb $12 . \quad$ Available from: http://business.inquirer.net/107377/first-come-first-served-policy-for-reprojects. Accessed 2018 Jan 22.

62. Asian Development Bank (ADB). Philippines Energy Sector Assessment, Strategy, and Roadmap. 2018 Oct. Available from: https://www.adb.org/sites/default/files/publication/463306/philippinesenergy-assessment-strategy-road-map.pdf. Accessed 2019 Nov 10.

63. Brückmann R. Administrative Procedures. Rules and Processes for On-Grid PV Project Development in the Philippines. Berlin (Germany): Deutsche Gesellschaft fur Internationale Zusammenarbeit (GIZ) GmbH; 2013 May 13. Available from: https://www.doe.gov.ph/sites/default/files/pdf/netmeter/ giz2013-en-administrative-procedures-philippines-off-grid.pdf. Accessed 2019 May 15.

64. Fajardo J, Ruales M, Wilhelm B. Solar PV Guidebook Philippines: Legal and Administrative Requirements for the Development and Connection of On-grid Solar PV Projects in the Philippines. Manila (Philippines): Deutsche Gesellschaft für Internationale Zusammenarbeit (GIZ) GmbH; 2014 Aug 14. Available from: https://www.international-climate-initiative.com/fileadmin/ Dokumente/2014/giz 2014 Solar PV Guidebook Philippines.pdf. Accessed 2019 May 15.

65. Philippine Department of Energy (DOE). 31st Electric Power Industry Reform Act (EPIRA) Implementation Status Report. Manila (Philippines): DOE; 2017 October. Available from https://www.doe.gov.ph/electric-power/31st-statusreport-epira-implementation. Accessed 2019 Jun 20.

66. McCoy A. An Anarchy of Families: State and Family in the Philippines. Chicago (US): the University of Chicago Press; 1994.

67. Rudnick H, Velesquez C. Learning from Developing Country Power Market Experiences: The case of the Philippines. The World Bank Group of Energy and Extractives Global Practice. Washington, D.C. (US): The World Bank Group; 2019 Jan. Available from: http://documents.worldbank.org/curated/en/428331548771494859/Learningfrom-Developing-Country-Power-Market-Experiences-The-Case-of-thePhilippines. Accessed 2020 Jan 10.

68. San Miguel Corporation. Power and Energy. Available from: http://www.sanmiguel.com.ph/article/power-\&-energy. Accessed 2018 Jan 16.

69. SMC Global Power Holdings Corporation. 2016 Annual Report. Available from: http://smcglobalpower.com.ph/ir.php?i=17-A. Accessed 2017 Nov 8.

70. Aboitiz Power Corporation Homepage. Aboitiz Power. Our Businesses. Available from: https://aboitizpower.com. Accessed 2018 Jan 16.

71. First Gen Homepage. https://www.firstgen.com.ph. Accessed 2019 Jul 26.

72. Energy Development Corporation Homepage. 2019. Available from: https://www.energy.com.ph. Accessed 2019 Jul 26. 
73. Yu M. The Philippine biggest power distributor: Manila Electric Company (MERALCO). 2017 Jul 22. Available from: https://finance.yahoo.com/news/philippines-biggest-power-distributormanila-000739725.htm. Accessed 2018 Jan 16.

74. Manolo S. San Miguel ups Meralco stake, power struggle looms with PLDT. Reuters. 2009 May $13 . \quad$ Available from: https://www.reuters.com/article/meralco-sanmiguel/san-miguel-upsmeralco-stake-power-struggle-looms-with-pldt-idUSMAN46954020090513. Accessed 2019 Nov 22

75. MERALCO PowerGen Corporation Homepage. Available from: https://meralcopowergen.com.ph/. Accessed 2019 May 28.

76. Oplas BS Jr. The Philippine electric market: monopoly and competition. Business World. 2015 Aug 14. Available from: http://www.bworldonline.com/content.php?section=Weekender\&title=thephilippine-electricity-market-monopoly-and-competition\&id=113411. Accessed 2018 Feb 10.

How to cite this article:

Saculsan PG, Mori A. Why Developing Countries Go through an Unsustainable Energy Transition Pathway? The Case of the Philippines from a Political Economic Perspective. J Sustain Res. 2020;2(2):e200012. $\underline{\text { https://doi.org/10.20900/jsr20200012 }}$ 